University of Wollongong

Research Online

Faculty of Social Sciences - Papers (Archive) Faculty of Arts, Social Sciences \& Humanities

2013

The experience of transitioning two adolescents with asperger syndrome in academically focused high schools

Roselyn M. Dixon

University of Wollongong, roselyn@uow.edu.au

Kathleen Tanner

University of Wollongong, ktanner@uow.edu.au

Follow this and additional works at: https://ro.uow.edu.au/sspapers

Part of the Education Commons, and the Social and Behavioral Sciences Commons

Research Online is the open access institutional repository for the University of Wollongong. For further information contact the UOW Library: research-pubs@uow.edu.au 


\title{
The experience of transitioning two adolescents with asperger syndrome in academically focused high schools
}

\author{
Abstract \\ Adolescents with Asperger syndrome (AS) are increasingly being placed in academically focused high \\ schools. These students, although academically able, may not be coping with the wider classroom and \\ social demands of transition to, and within, the high school environment. Schools are keen to enrol these \\ students. However, there appears to be a gap between the rhetoric and the reality relating to the varying \\ perceptions of key stakeholders. In this paper we present the results of a study of the perceptions of key \\ stakeholders in the transition of two students with AS into two academically focused high schools. Eight \\ participants were involved in semistructured, one-on-one interviews. Key stakeholders included executive \\ teachers, classroom teachers, students and their caregivers. The results indicated that there were some \\ differences in the teacher and caregiver perspectives across physical, academic and social areas of \\ transition.
}

\section{Keywords}

Asperger syndrome, transition, adolescents, high school, qualitative research, caregiver perspective

\section{Disciplines}

Education | Social and Behavioral Sciences

\section{Publication Details}

Dixon, R. M. \& Tanner, K. (2013). The experience of transitioning two adolescents with asperger syndrome in academically focused high schools. Australasian Journal of Special Education, 37 (1), 28-48. 


\section{Australasian Journal of Special Education}

http://journals.cambridge.org/JSE

Additional services for Australasian Journal of Special Education:

Email alerts: $\underline{\text { Click here }}$

Subscriptions: $\underline{\text { Click here }}$

Commercial reprints: $\underline{\text { Click here }}$

Terms of use : $\underline{\text { Click here }}$

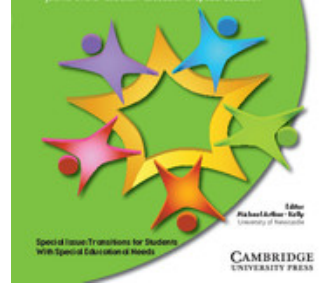

\section{The Experience of Transitioning Two Adolescents With Asperger Syndrome in Academically Focused High Schools}

Roselyn M. Dixon and Kathleen Tanner

Australasian Journal of Special Education / Volume 37 / Special Issue 01 / July 2013, pp 28 - 48 DOI: 10.1017/jse.2013.5, Published online: 03 May 2013

Link to this article: http://journals.cambridge.org/abstract S1030011213000055

How to cite this article:

Roselyn M. Dixon and Kathleen Tanner (2013). The Experience of Transitioning Two Adolescents With Asperger Syndrome in Academically Focused High Schools. Australasian Journal of Special Education, 37, pp 28-48 doi:10.1017/jse.2013.5

Request Permissions : $\underline{\text { Click here }}$ 


\title{
The Experience of Transitioning Two Adolescents With Asperger Syndrome in Academically Focused High Schools"
}

Roselyn M. Dixon and Kathleen Tanner

University of Wollongong, NSW, Australia

\begin{abstract}
Adolescents with Asperger syndrome (AS) are increasingly being placed in academically focused high schools. These students, although academically able, may not be coping with the wider classroom and social demands of transition to, and within, the high school environment. Schools are keen to enrol these students. However, there appears to be a gap between the rhetoric and the reality relating to the varying perceptions of key stakeholders. In this paper we present the results of a study of the perceptions of key stakeholders in the transition of two students with AS into two academically focused high schools. Eight participants were involved in semistructured, one-on-one interviews. Key stakeholders included executive teachers, classroom teachers, students and their caregivers. The results indicated that there were some differences in the teacher and caregiver perspectives across physical, academic and social areas of transition.
\end{abstract}

Keywords: Asperger syndrome, transition, adolescents, high school, qualitative research, caregiver perspective

The transition from primary school (Years 1-6 of schooling) to high school (Years 7-12 of schooling) for any student can present many challenges for parents, students and educators. In the State of New South Wales (NSW), Australia, the 'Middle Years' strategy 2006-2009 has identified transition as a key factor influencing the continuity of learning for all students. A component of this strategy requires schools to develop specific transition programs to identify a key person in every school to coordinate transition [programs] ... [as well as] provide additional professional learning and Intranet [support]' for all staff (NSW Department of Education and Training [NSW DET], 2006, p. 11).

Transition to secondary school is not necessarily positive for all students. It has been associated with declines in performance, attendance and self-esteem (Adreon \& Stella, 2001; Hertzog, Morgan, Diamond, \& Walker, as cited in Maras \& Aveling, 2006). It may also be associated with anxiety and increasing stress levels (Dalton, 2009; Jindal-Snape, Douglas, Topping, Kerr, \& Smith, 2006). Morgan (1999), cited in Maras and Aveling (2006), suggests that 'students struggling with the transitional process may manifest their difficulties in sudden outbursts of inappropriate behaviour, detachment from

Correspondence: Dr Roselyn M. Dixon, University of Wollongong, Faculty of Education, NSW 2522,

Australia. E-mail: roselyn@uow.edu.au

${ }^{*}$ This manuscript was accepted under the Guest Editorship of Chris Forlin. 
their new environment, or chronic illness' (p. 196). Perceived quality of school life (Roeser, Midgley, \& Urdam, 1996), including poor quality of teacher-student relationships (Ainley, 1995) and student-student relationships (McMaugh \& Debus, 2000), increases vulnerability linked to transition.

Transitional phases can be particularly challenging for young people with Asperger syndrome $^{1}$ (AS), and for all associated stakeholders, such as parents/caregivers and educational professionals (Jindal-Snape et al., 2006; Newsome, 2000). These challenges are associated with the underlying characteristics of students with AS that include difficulties in the areas of social interaction, communication and behaviour. One difficulty that is frequently reported is the need to be 'prepared for changes in routine' (Safran, 2002, p. 64). Students 'exhibit a need for sameness or predictability in their environments, which may result in inflexible behavior when their environment or an established routine is altered' (Adreon \& Durocher, 2007, p. 273). For these students it is logical to assume that there would be additional needs in the areas of physical, social and academic resources and supports.

Examination of the transitioning of students with learning and other disabilities throughout different school settings and beyond is well documented in the literature (Maras \& Aveling, 2006; Patton, Cronin, \& Jairrels, 1997; Winn \& Hay, 2009); however, reference specifically to students with AS is minimal (Adreon \& Durocher, 2007; Adreon \& Stella, 2001). Students with AS may find transition to secondary settings particularly difficult as some of the characteristics of AS become more visible (Barnhill, 2004), due in part as a response to having to navigate a larger environment, but more so exacerbated by the organisational features of secondary schools (Adreon \& Stella, 2001). These features may include students having their own lockers, having different teachers for different subjects, and moving to different rooms throughout the day (Rossetti \& Goessling, 2010). All of these organisational/physical features may also affect social factors, such as the student with AS finding the correct material for the next class, finding his or her way around the school, interacting appropriately with other staff and students in the interim period, depending upon the social situation. When students with AS arrive at another classroom, they have to meet the expectations of this new classroom and teacher, in addition to higher levels of expectation for behaviour and academic achievement (Hay \& Winn, 2005). Added to this is the intellectual transitioning from subject to subject that requires a shift in attention that can be exacerbated by the executive functioning difficulties experienced by the student with AS (Graetz \& Spampinato, 2008). These challenges are separate to the social difficulties many students with AS seem to experience moving into, and operating within, the playground.

Increasing numbers of students with AS are being identified and most of these students in NSW will receive their education in mainstream schools with special education services support (Hay \& Winn, 2005). However, AS presents a conundrum. Higher intellect is commonly associated with AS (Attwood, 2007; Frith, 2004; Webb et al., 2005), and these students will often be found in schools that cater for students of higher academic ability. These types of schools are called selective schools in NSW. Their mandate is to 'cater for highly achieving academically gifted students. These schools can provide intellectual stimulation by grouping gifted and talented students together, concentrating school resources and using specialised teaching methods' (NSW DET, 2009, p. 2). Entry to the school is based on academic merit and is determined by primary school assessment scores in combination with the NSW Department of Education's Selective High Schools Placement Test.

Selective schools in the NSW Government Department of Education and Communities (DEC) system and academically focused independent high schools are willing to enrol these students; however, there has not been a corresponding increase in the knowledge of 
AS by the main stakeholders. These stakeholders include mainstream teachers, executive teachers, support staff and parents/caregivers. In fact, Ivey (2004) claimed that home and school misunderstandings were commonly reported by parents of children with AS, and Hay and Winn (2003) emphasised communication and collaboration difficulties as exacerbating these misunderstandings. Geenen, Powers, and Lopez-Vasquez (2001) identified that parents' stress levels were exacerbated by adversarial relationships with professionals. Ivey (2004) also argued that parent and student perceptions were often missing from the literature. Newsome (2000) claimed that 'understanding the perceptions held by parents is vitally important to practitioners and researchers' (p. 19), in particular those working with children on the autism spectrum.

Although studies linked to the general population of students have been conducted that focus on student perceptions and their experiences of the transition process from primary to high school (Akos, 2002; Ganeson \& Ehrich, 2009), Ivey (2004) claimed that perceptions of students with AS have not been documented. A study by Hay and Winn (2005) presented the perspectives of teachers, special education teachers, students and caregivers in relation to educational issues arising from secondary schooling, but did not specifically include transition issues.

Numerous strategies have been recommended to support the transition needs of students with AS (Konza, 2005; Maras \& Aveling, 2006). Most of these strategies focus on physical or practical requirements, such as learning about the physical environment and the timetable. Strategies that more specifically target the needs of students with AS might include a differentiated curriculum that focuses on visual learning techniques rather that verbal techniques, comprehensive social skills programs, understanding of fine and gross motor clumsiness, and provisions for sensory sensitivities and special interests in an inclusive high school setting (Adreon \& Stella, 2001; Ennis \& Manns, 2004). Lawrence (2010), in a transition guide for parents, identifies a range of practical strategies within a 'transition checklist'. There is, however, a need for research that goes beyond the practical strategy base and considers academic and social transitioning. This call for research is supported by Wehman and Thoma (2006), who indicate that academic, social, emotional and physical factors need to be addressed equally.

In this study we aimed to identify the differing perceptions of key stakeholders (executives, teachers, caregivers and students) within two separate schools regarding the transition procedures that were identified and put into practice before transition to high school occurred, and the subsequent procedures that were identified for transition between year levels. Stakeholders' perceptions of the structure and expectations of daily school life were also recorded. A qualitative case study approach was chosen so that a depth of information could be gained and views from different stakeholders could be compared and contrasted.

\section{Method}

Qualitative case study methodology using semistructured interviews was undertaken at two schools where each school was considered to be the unit of analysis. This allowed for better contrast between the two entities (Yin, 2009). The study involved a total of eight individual face-to-face interviews with a member of the school executive, a classroom teacher, a student with AS and their caregiver from each school.

\section{Setting}

Maranoa School ${ }^{2}$ is an academically focused coeducational independent high school in a semirural setting on the outskirts of a major metropolitan centre. It forms part of a 
TABLE 1

School Staff Participants

\begin{tabular}{|c|c|c|c|c|}
\hline & Age & Gender & $\begin{array}{l}\text { Teaching } \\
\text { experience } \\
\text { (years) }\end{array}$ & Key responsibilities \\
\hline Executive 1 (E1) & 40 & M & 15 & Head of middle school (7-9); support teacher \\
\hline Executive 2 (E2) & $40+$ & M & $20+$ & $\begin{array}{l}\text { Deputy principal; coordinator learning } \\
\text { support team }\end{array}$ \\
\hline Teacher 1 (T1) & $30 \mathrm{~s}$ & $\mathrm{~F}$ & $10+$ & Head teacher Year 7; class teacher \\
\hline Teacher 2 (T2) & $30 \mathrm{~s}$ & M & $10+$ & $\begin{array}{l}\text { Patron teacher for student with AS; class } \\
\text { teacher }\end{array}$ \\
\hline
\end{tabular}

TABLE 2

Student Participants

\begin{tabular}{|c|c|c|c|c|c|}
\hline & Age & Year & AS diagnosis & Previous school setting & Current school setting \\
\hline Mark & 14 & 7 & Pre-primary & $\begin{array}{l}\text { Independent co-ed K-12 } \\
\text { Primary campus (K-6) }\end{array}$ & $\begin{array}{l}\text { Same school } \\
\text { Mid campus (7-10) }\end{array}$ \\
\hline Angus & 15 & 9 & Primary & Public primary school (1-6) & $\begin{array}{l}\text { Selective public high } \\
\text { school }\end{array}$ \\
\hline
\end{tabular}

larger campus that caters for students from kindergarten to Year $12(\mathrm{~K}-12)$. Its population encompasses a broad spectrum of levels but also includes a selected high-academic stream determined through an academic selection exam. Shacklin School is a fully selective coeducational public high school (Years 7-12) situated in a large regional town. Students are selected based on academic merit. Marks from the NSW Department of Education's Selective Placement Test and primary school assessment scores determine eligibility.

\section{Participants}

A senior executive, whose responsibilities included supervision of other staff and students, and a classroom teacher were interviewed from each school. Executive 1 (E1) from Maranoa School was the head of the middle school (Years 7-9) and was directly involved in liaising with caregivers and staff about individual student needs. Executive 2 (E2) from Shacklin School held the position of deputy principal and coordinated the school's learning support team, which ensures the needs of all students in the school are being met. A key feature of the learning support team is the facilitation of collaborative planning between teachers, support staff, caregivers and students. Although E2 was an experienced teacher and administrator, he also indicated he had a wealth of experience from a personal and academic perspective working with students with AS. Previously he had been president of the local autism association.

Teacher 1 (T1) from Maranoa School was the head of Year 7 whose responsibility was to inform and guide other staff members in regard to individual student needs. Teacher 2 (T2) from Shacklin School was allocated the role of patron teacher for the student with AS throughout his schooling from Year 7 to 12. This role included informing staff about the student's needs from year to year and liaising with the executive staff and learning support team.

Mark, from Maranoa School, and Angus, from Shacklin School, were the student participants identified by each school. Both students received an early diagnosis of AS, with Mark experiencing more difficulties prior to attending high school. Mark had attended the $\mathrm{K}-12$ school since kindergarten. He began his schooling in an early intervention program 
TABLE 3

Caregiver Participants

\begin{tabular}{lcccc}
\hline & Primary & & Children in & \\
& caregiver & Sole parent & family & Background \\
\hline Caregiver 1 (Mark's mum) & Yes & No & 2 & High socioeconomic \\
Caregiver 2 (Angus's mum) & Yes & Yes & 2 & Middle socioeconomic \\
\hline
\end{tabular}

in a satellite class for students with autism but was moved to Maranoa School, as it was his family's goal that he attend the same school as his sibling.

Angus, on the other hand, had attended a public school from kindergarten to Year 6 in his local area and successfully passed the NSW Department of Education's Selective Placement Test and began Year 7 at Shacklin School. This school is out of his residential area and requires him to either catch the local bus or be transported by his mother.

Both students' caregivers identified as the primary caregiver. They were approached by the school to participate in the research and gave permission for their child to participate.

\section{Instruments}

The following four key categories linked to effective transitioning were identified from a systematic comparison (Corbin \& Strauss, 2008) of the review of the literature:

1. Awareness, knowledge and understanding of students with AS

2. Types and effectiveness of transition procedures

3. Internal transitioning procedures

4. Involvement of others in transitioning

These four categories provided a framework for development of the interview questions. Stimulus questions were then customised for each group of stakeholders in order to derive their personal perceptions. Examples of customised questions for each category are included in Table 4.

Eight individual interviews were conducted by two experienced qualitative female researchers (the authors), both of whom are experienced in working with families and students with autism spectrum disorder. Each researcher was responsible for one school and the four associated interviews. Although the interviews were semistructured, both researchers used the same stimulus questions; however, the probes used to elicit further information from each of the participants differed. The length of interviews ranged from 10 minutes with Mark, to 90 minutes with each of the caregivers. Executives and teachers talked within an hour timeframe due to school-based time constraints.

\section{Procedures}

Convenience sampling was used for this study. Principals were initially approached to identify students with AS and to provide access to relevant staff and caregivers. Interview times and places were arranged to suit the participants. Single interviews for the teachers were conducted in school interview rooms. Single interviews for both caregivers and students were in their own homes at their request. Caregivers were asked to prepare their child in advance of the interview process. All interviews were audio-recorded and transcribed in full. 
TABLE 4

Customised Interview Questions

\begin{tabular}{|c|c|c|c|}
\hline Executives & Teachers & Caregivers & Students \\
\hline \multicolumn{4}{|c|}{ Category 1: Awareness, knowledge and understanding of students with AS at the school } \\
\hline $\begin{array}{l}\text { How many students with diagnosed AS } \\
\text { are attending your school? }\end{array}$ & $\begin{array}{l}\text { Are you aware of any students in your } \\
\text { classes that have been diagnosed } \\
\text { and disclosed they have AS? }\end{array}$ & $\begin{array}{l}\text { Tell me about the way in which the } \\
\text { school was informed about your } \\
\text { child's needs. }\end{array}$ & $\begin{array}{l}\text { Which people at your school know } \\
\text { you have AS? }\end{array}$ \\
\hline $\begin{array}{l}\text { How are you informed of these } \\
\text { students' individual needs? }\end{array}$ & In what ways were you informed? & $\begin{array}{l}\text { Have there been times when your child } \\
\text { has experienced difficulties due to } \\
\text { academic, physical or social } \\
\text { transitioning? }\end{array}$ & Who told them? \\
\hline \multicolumn{4}{|c|}{ Category 2: Types and effectiveness of transition procedures } \\
\hline \multirow[t]{2}{*}{$\begin{array}{l}\text { Describe the type of support your } \\
\text { school provides: } \\
\text { - Before the new school year begins } \\
\text { - At the beginning of the school year } \\
\text { - Throughout the school year. }\end{array}$} & $\begin{array}{l}\text { Same as executive - but from } 2 \\
\text { perspectives: } \\
\text { - What does the school do? } \\
\text { - What do you do? }\end{array}$ & $\begin{array}{l}\text { What did the primary school do to help } \\
\text { your child transition into high } \\
\text { school? } \\
\text { Describe what the high school did. }\end{array}$ & $\begin{array}{l}\text { What was the most difficult thing that } \\
\text { happened moving from primary to } \\
\text { high school? } \\
\text { Series of prompted questions linked } \\
\text { to before, beginning and during. }\end{array}$ \\
\hline & & $\begin{array}{l}\text { Who coordinated and/or made sure the } \\
\text { process was effective? }\end{array}$ & \\
\hline \multicolumn{4}{|l|}{ Category 3 : Internal transitioning procedures } \\
\hline $\begin{array}{l}\text { Do you consider the need to put in } \\
\text { place transition processes as the } \\
\text { student moves from year to year } \\
\text { within the school? } \\
\text { From class to class? } \\
\text { If yes, what does your school do? }\end{array}$ & $\begin{array}{l}\text { How do you prepare a student for: } \\
\text { - Movement into the next year level? } \\
\text { - Class to class? } \\
\text { - Academic to break time? }\end{array}$ & $\begin{array}{l}\text { How is the school assisting in transition } \\
\text { from one year to the following year? } \\
\text { - Class to class? } \\
\text { - Academic to break time? }\end{array}$ & $\begin{array}{l}\text { When you go into Year } \mathrm{X} \text { what will be } \\
\quad \text { different to this Year? } \\
\text { Who has told you? } \\
\text { What did they tell you? } \\
\text { Questions re: } \\
\text { - Class to class } \\
\text { - Class to playground/break time }\end{array}$ \\
\hline \multicolumn{4}{|c|}{ Category 4: Involvement of others in transitioning } \\
\hline $\begin{array}{l}\text { To what extent do you involve the } \\
\text { student, family and/or previous } \\
\text { educationalists in developing and } \\
\text { conducting transition procedures? }\end{array}$ & $\begin{array}{l}\text { Who is involved in transition } \\
\text { procedures? }\end{array}$ & $\begin{array}{l}\text { How does the school involve you in } \\
\text { transition? Are you expected or } \\
\text { invited to be involved? }\end{array}$ & $\begin{array}{l}\text { Who helped you when you went from } \\
\text { primary to high school? } \\
\text { Class to class? } \\
\text { Class time to break time? }\end{array}$ \\
\hline
\end{tabular}




\section{Ethical Considerations}

This research was approved by the Human Research Ethics Committee of the University of Wollongong, NSW, the NSW State Education Research Approval Process (SERAP) and the Association of Independent Schools of NSW Ethics Board.

\section{Data Analysis}

On completion of the transcription of interviews, each transcript was open-coded by the two researchers who independently performed line-by-line coding. Open coding involved the process of identifying concepts from the chunks of raw interview data (Corbin \& Strauss, 2008). Thematic analysis of qualitative data was conducted to identify emerging similarities, differences and themes among the data (Braun \& Clarke, 2006). The researchers read within and among all data numerous times from beginning to end so as to become familiar with certain themes and to determine categorisation of data (Stake, 2006). Such processes involved open and axial coding in which the researchers progressed from the identification of specific codes from within each dataset to the relation of categories among extensive data (Creswell, 2007). Memos were prepared containing preliminary codes and themes on the basis of the four categories that had been identified from the literature (which had informed the original interview questions). However, analysis was not totally bound by these preexisting categories (Rubin \& Rubin, 2005). Collaboration and consensus on categories was achieved through re-reading and discussion of transcripts and identification of relevant responses/perceptions. The researchers considered it more important to consider the commonalities and themes across all participants, and therefore discrete coding was not undertaken because it tends to concentrate on language features. Further analysis by the researchers (Corbin \& Strauss, 2008) led to the emergence of three subcategories of transition.

\section{Results}

The results are presented using the categories that were derived from the literature and provided the structure for the interviews.

\section{Category 1: Awareness, Knowledge and Understanding of Students With AS at Their School}

Both executives were aware of and indicated students with a diagnosis of AS in their school, but there was a distinct difference in their knowledge, experience and understanding of catering for these students' needs. E2 from Shacklin School referred to his wealth of experience from a personal perspective, having been president of the local autism association, and from an academic perspective he referred to himself as 'a resource' to support other members of staff and students. He also initiated and ran individualised programs with students with AS throughout their schooling, dependent on their needs.

E1 from Maranoa School felt that as the majority of students with AS had been enrolled in the school since kindergarten this was 'a positive' as their histories were well known to all staff and passed on. He believed that 'not all these students need specific support' (E1). However, in regard to Mark, the identified student participant, he spoke of the need for an information session run by the school 'where we had invited his mum to come in ... [and] his speech pathologist came in and talked' (E1). 


\section{TABLE 5}

School-Based Procedures to Inform Teachers of Individual Student Information

\begin{tabular}{lc}
\hline Teacher 1 & Teacher 2 \\
\hline $\begin{array}{l}\text { Beginning of the year: Head of Year meets with all } \\
\text { teachers who will have students with special } \\
\text { needs in their classes. }\end{array}$ & $\begin{array}{c}\text { Individual student information sheets placed } \\
\text { around the school for the benefit of teachers. }\end{array}$ \\
$\begin{array}{l}\text { Learning support register: Includes student } \\
\text { information, such as characteristics, behaviours } \\
\text { and effective classroom strategies. }\end{array}$ & $\begin{array}{c}\text { All teachers informed of an individual student's } \\
\text { needs at beginning of their schooling. }\end{array}$ \\
$\begin{array}{l}\text { Explicit information on student file in database. } \\
\text { Patron teacher informs all individual staff who will } \\
\text { teach identified student on a semester-to- } \\
\text { semester and year-to-year basis. } \\
\text { clearly marked next to student's name. }\end{array}$ & \\
\hline
\end{tabular}

Both of the teachers were aware of students with AS enrolled at their schools, and they identified school-based procedures to inform teachers of individual student information. These procedures are listed in Table 5.

T1 said she was aware of five to 10 students who had characteristics of AS, whereas her executive (E1) referred to four who had a diagnosis. T2, on the other hand, was unaware of explicit numbers; however, E2 said there were three with a diagnosis at the school. Differences between T1 and T2 emerged relating to knowledge and understanding of the students. T1 had attended a parent information session specifically regarding Mark; in contrast, T2 first became aware of Angus when his mother brought him to the school in Year 6 to 'introduce him to myself because I am also his year patron' (T2).

T1 and T2 differed in their knowledge of AS. T2 was aware of the visual learning modality and recounted that it had been the focus of past school-based professional development: 'It is instilled in us a lot and it has been done for years ... [however] I don't know whether teachers would actually go out of their way [to adjust their teaching to suit learning styles]' (T2).

Both caregivers initiated opportunities to make schools and teachers aware of the needs of their children when transitioning into the high school. Their initial emphasis was on the physical layout of the schools. Even though Mark was transitioning within campuses and Angus was transitioning to an unknown environment outside of his local area, both caregivers perceived the need to become familiar with the physical environment as a priority. Angus's mother initiated a number of visits prior to Year 7, as she said her son needed 'a fair bit of practice in the layout of the school - he went there a few times' (Angus's mum).

One key difference was that Mark's mother had continually liaised with the school and individual teachers on an informal needs basis throughout her son's schooling. Each year she suggested transition procedures between classes and years. Before transitioning to Year 7, she requested a meeting with the head of the middle school (E1) and she organised an open information day for Year 7 teachers. (This is in contrast to the executive's and teacher's perceptions.) During these sessions Mark's individual characteristics and supportive strategies were identified and discussed. Mark's mother and his speech therapist (whom she paid to provide support) were the key speakers. Mark's mother also indicated she knew some staff had attended professional development sessions about ASD during the time he had been at the school.

Angus's mother, on the other hand, was not approached to be involved in any of the transition planning or processes. She believed that the 'itinerant worker/counsellor' 
(support teacher autism) initially contacted the high school and then E2 visited the primary school to meet with the support teacher and to meet Angus. Angus's mother was proactive in providing information to the high school regarding her son's individual characteristics and needs. She presented a comprehensive letter to the head of the learning support team (E2) at the beginning of Year 7. It provided 'a list of things which may help teachers understand him and be aware of potential management issues' (Angus's mum). She was unaware as to whether it had been passed on to individual teachers.

Both students were aware of their diagnosis. Mark said, 'Everyone at the school knows. My mum told them', but was unable to articulate any further awareness or responses to his AS by other people. Angus stated that his close friends at school knew he had AS, but he was unsure which teachers were aware: 'I think some of the teachers know and probably [principal] told the teachers' (Angus).

While Angus understood that some, but not all, teachers might have been aware of his AS, he said that some found it difficult to adjust to his need for clear, explicit and correct instruction. His inflexibility presented particular confusion when teachers gave unclear or incorrect instructions when transitioning between classes: 'Go to C6 and then there are people waiting at $\mathrm{C} 6$ telling us to go to E2 - it gets a bit annoying and frustrating — they must get it right in the first place' (Angus).

\section{Category 2: Types of Transition Procedures}

All stakeholders were asked to identify support provided by the school in transitioning from Year 6 to Year 7 and throughout the year (see Appendices A and B). The majority of support identified was implemented before the commencement of Year 7.

Although similar procedures were identified by the majority of stakeholders, the claims of ownership as to who initiated them varied. The types of procedures identified across both schools focused predominantly on physical transitioning. Mark's mum said she had initiated transition procedures for her son, whereas an itinerant support teacher (autism), who was linked to the primary school, was instrumental in supporting the transition process for Angus. Both caregivers indicated they were not informed of the school-based procedures during the commencement of, and ongoing throughout, the year. Staff-implemented strategies, such as a safe haven at both schools and a model club at Maranoa school for Mark, were not accessed by either student. Angus said that social transitioning was quite difficult because of his inability to make friends easily, and the school was not supportive of his needs.

Mark's mum stated that the school was very supportive; however, that there was little evidence to support a collaborative consultative approach was reflected in the comments by E1, who stated that it's 'policy on the run' (E1).

There was no evidence that the strategies in the letter from Angus's mum had been implemented. However, there were definitely more procedures in this school, identified by E2 and T2, for follow-up and informing new staff of the student's individual needs each semester.

\section{Category 3: Internal Transitioning}

Neither of the executives or teachers indicated any specific procedures or strategies for supporting internal transitioning between classrooms and break times. E1 stated that if difficulties arose during these transition times and they could not handle the student's responses, they would request assistance from Mark's parents to withdraw him from the school. In contrast, E2 from Angus's school believed that strategies to cope 
with transition within a day-to-day context were less important than the emphasis on providing individual students with the knowledge and understanding of their AS and the skills to be able to self-regulate their own behaviour during transition times. He believed students with AS need to 'fully understand what is happening to themselves so they can develop strategies to deal with issues themselves' (E2). E2 worked on an individual one-on-one basis to support students in this context. He also stressed the importance of understanding both the influence of the student's AS characteristics but also the adolescent changes that may have influenced their learning and school experiences. He stated

You have to teach a lot of the skills, a lot of the things that would be normal for people you know they just learn by osmosis. These kids need to actually be taught various social nuances and things along those lines so we'd have various programs basically, and especially with these kids going through puberty and finding change within their emotional self, family setting and their physical setting that we have to organise various changes in our program. (E2)

There was a difference between the two schools in terms of preparation for transition between year levels. Maranoa school executive and teacher stated that no preparation had been begun for the transition into Year 8 even though it was to begin in Term 4 of the current year. A 'presumption of familiarity' was expressed by both the executive and teacher, stating the subjects remained the same, as does his tutor teacher. The executive suggested that similar procedures as before 'may' need to occur. The teacher, when asked 'How do you prepare a student for movement in to the next year level?', was unable to clearly articulate any set procedures. She said she would meet with the new head of the year to discuss the changeover period, during which time 'things that have worked and things that have helped will be passed on' (T1).

Shacklin School, on the other hand, had set in place a teacher who was referred to as the student's patron teacher. T2 was allocated this role and was responsible for liaising with the student and being the first point of contact for both staff and the student. With the school operating on a semester-to-semester basis, the executive and their patron teacher indicated any changes to classes and teachers in advance, to both the student and individual staff members. In order to make this transitioning smoother, within and across years, patron teachers were allocated to support the student from Year 7 to 12 to provide a sense of constancy. As well as this, the executive worked 'behind the scenes' from semester to semester and year to year.

Angus's mum indicated that difficulties were not necessarily linked to physical transitioning but were more related to academic transitioning, in particular the lack of organisational support from year to year and semester to semester. T2 supported this claim saying internal transitioning is 'just the same for everybody'. Although Maranoa School did not plan specifically for internal transitioning, they did, however, place extensive importance on the need to adjust academic content and presentation and prepare Mark for events such as timetabling changes. This was evident during a recent exam period when the student reacted in a negative manner due to stress linked to an unknown situation.

Mark, when asked about transitioning, simply responded with 'it will be good'. Angus perceived the structure of Year 7 made the ongoing transition easier than that of following years. In Year 7 students are allocated to a specific class grouping for the entire year, for example, 'E7s', and attendance at all subjects is with that group. From Year 8 and onwards, different subjects may have different groups of students, which 'increases confusion'. 


\section{Category 4: Involvement of Others in Transitioning}

Executive members, teachers, caregivers and other staff were identified as being involved in both the initial and ongoing transition process, but there were differences in the varying degree of involvement from each of these members. Apart from access to the expert knowledge of the itinerant support teacher (autism) that Shacklin School had, there were no significant differences in the individuals involved; however, the extent of caregiver involvement was considerably different. Involvement of the students was not evident.

The executive from Maranoa School said that a range of teaching staff, from both the junior and senior school, were involved in the initial transition process from Year 6 to 7, including an open forum for all interested staff, not specifically those working with Mark. Over 20 teachers attended. The executive from Shacklin School identified the high school learning support team as actively supporting the transition process. An itinerant support teacher (autism) from Angus's primary school was also identified by both the executive and Angus's mum as a key informant for the high school learning support team. They also provided a range of visual resources for the student prior to the commencement of high school.

T1 from Maranoa School referred to constant consultation with Mark's mum in relation to day-to-day issues and acknowledged her as a valuable resource, particularly working through school issues at home. T2 from Shacklin School, a science teacher, had the role of Angus's patron teacher and was selected on the assumed commonality of interest due to Angus's acknowledged strength in science.

Mark's mum spoke of the constant contact that related more to managing her son's behaviour as opposed to collaborative planning for changes in routines and transitioning. She said the school was very supportive, but she had to proactively prompt staff and provide answers or strategies for them to assist him both academically and socially. In response to his recent obsession with garbage and littering, the school's response was to 'talk to him' and rely on the caregiver to deal with it at home. Both the executive and caregiver stated that Mark's sister was also called upon, but more so to inform the caregiver of incidents when she was unavailable. The caregiver and school had expectations of the consistent need for support, but had not articulated how this would happen, other than through the day-to-day management of issues. Mark's mum claimed 'there is always something coming up'.

Angus's mum made reference to his Year 6 class teacher prior to transition. She perceived the teacher's approach to preparation for transition was to make comments that actually increased her son's stress and anxiety levels, and he anticipated that high school would be worse than it actually turned out to be. Angus's mum initially liaised with the patron teacher, whom she believed to be the learning support team 'coordinator' from the high school. She was unaware that the executive was actually the coordinator. She provided a letter to the patron teacher outlining some of her son's characteristics and some practical suggestions to support his learning. She felt that a letter would have more impact, as she believed that some teachers would not respond to her requests if she went up and spoke to them face to face. Although Angus's mum indicated that she had requested an allocation of teacher aide time for her son, no reference was made by any other stakeholder as to whether this was actually provided and, if so, their role delineation.

At no time was there any indication that Mark had been consulted about his transitioning needs. He did, however, identify the executive, teacher, speech pathologist and caregiver as 'helping him'. Angus initially claimed that he 'had helped himself' in transitioning from primary to high school. After prompting, he recalled the executive had 'sort 
of helped but was not forthcoming with any details. He also indicated that his patron teacher 'showed me around' and told him 'if I had a question about a subject go and ask them' (Angus). He also indicated that he did not want to be identified as requiring help.

\section{Emergence of Three Subcategories}

The results from both case studies indicated that there were differences as to how each of the stakeholders perceived procedures (see Appendix A and B), their effectiveness and their implementation. Three subcategories of transition emerged from the data analysis: (a) physical, (b) academic, and (c) social transitioning, which will be further discussed. Neither student indicated that they had been consulted at any time as to their perceived needs in these areas, nor did any stakeholder indicate the development of an individual transition plan or individual education plan.

Physical transitioning. The importance of preparation for physical transitioning between new school environments was a focus for all adult stakeholders and it was perceived as being successful due to the prior planning procedures put in place at both schools. The use of visual aids, by Angus's school, in preparation for the initial physical adjustment to high school, was perceived as positive and necessary by all stakeholders, including Angus. He indicated that he valued the maps and visits prior to the commencement of Year 7, and these enabled him to quickly become accustomed to the layout. This familiarity was considered by the student to be a positive, and was supported by the school's clear labelling of room numbers and academic blocks and its 'logical structure'.

Stakeholders from Maranoa School agreed that the school structure provided for positive transitioning because (a) of it being a $\mathrm{K}-12$ campus and (b) all buildings are within close proximity to one another. All adult stakeholders identified similar organisational and resource-based procedures to assist the student in the transitioning process.

Although all staff participants were aware that the students required support, it was not apparent there would be ongoing provision for these needs in advance. There was no discussion of the structure of the next year's timetable, teachers, classrooms and allocated playground areas. In addition, no reference was made to the day-to-day realities of the physical aspects of playground experiences. Maranoa School did, however, allocate two 'buddies' (older peers) to introduce Mark to the playground on entry to Year 7; however, they were not encouraged to engage after this time as staff believed that a 'presumption of familiarity' would automatically occur.

Academic transitioning. For academic transitioning, school and home priorities appeared to differ markedly across both schools. Whereas the executive and teacher at Maranoa School focused on the academic adjustments linked to the student's behavioural responses, Mark's mum gave the impression that his academic needs were not her first priority. The executive and teacher did not describe procedures or strategies they were using to support the student in moving from one academic mode to another. They were aware of the need for flexible arrangements and adjustments, but awareness was usually a result of the student's negative behavioural responses rather than anticipation of needs.

Angus's mum, on the other hand, perceived academic organisation to be of utmost importance in supporting her son in the transition between subjects. She had put in place specific visual strategies using colour-coding strategies to alleviate the stress and confusion experienced by her son because of his poor organisational skills. She claimed minimal organisational support was provided in visual/written format. She stated that

At the beginning of the year or each term if he could have an outline of what was going to happen particularly in Year 7 ... a lot of information given out would be verbal and he would come 
home and he wouldn't know what to do or where to start cause he couldn't remember cause he wasn't taking in the verbal information, he needed to have it written. (Angus's mum)

Homework for each subject was one area of confusion that heightened anxiety because instructions and requirements were frequently verbal. Although she claimed to have followed up on this each term by specifically bringing Angus's needs to the head learning support teacher's attention, it remained unaddressed. When raised with the executive as to whether all staff were aware of Angus's need, he responded with 'they all know!' (E2). Similarly, the teacher stated that although all staff were aware of Angus's visual needs, 'I don't know whether teachers would actually go out of their way' (T2). This reflects a lack of perception by educationalists as to the stress, anxiety and constant source of tension that homework may cause in the home environment.

Angus's mum had been proactive in providing knowledge about her son's requirements (in the form of a detailed letter), but she felt it had gone unrecognised. This contrasted with the executive who indicated the importance of liaising with caregivers and argued that his role was to provide students with strategies to identify and deal with these difficulties by providing one-on-one opportunities to discuss and talk with the student. This has revealed an overlooked area regarding school-to-home transition in terms of homework and the support required for the student's cognitive and organisational shift to this environment.

Social Transitioning. Both schools were aware that the traditional camp for Year $7 \mathrm{~s}$, during their first week of high school, would be a socially stressful event. Mark was prepared by his mother for this event, whereas none of the stakeholders for Angus indicated that preparation for attendance at this camp was provided. However, the executive from Shacklin School advised that during camp individual programs were run to prepare students with AS for Year 7.

Staff referred to the proactive strategies of the provision of a safe haven (within both schools) and a model club (Maranoa School), indicating that the strategies have not achieved their goals because the students 'did not access them' (T2), in Mark's case, or 'did not need them' (T2), according to Angus's teacher. For Mark, all stakeholders communicated that the student was not socially integrated and clearly did not have a social group. There is no indication of support for Mark with skill acquisition and knowledge when transitioning within and outside of the classroom. Mark's mum says he 'loves the idea of having friends' and Mark stated that 'people are friendly but not friends'.

Angus's patron teacher said that Angus rarely used the safe haven because he believed the student had learnt to deal with playground bullying. The teacher perceived that this was directly related to the student's interest and high level of achievement in karate (provisional black belt).

Apart from these physical provisions for social support, no specific systematic social skill instruction was mentioned by any stakeholder.

\section{Discussion}

The purpose of this research was to provide information about the transition experience of teachers, parents and adolescents with AS in academically focused schools by collecting in-depth information using semistructured interviews with eight participants. Four broad categories, derived from the literature, guided the investigation and the initial analysis. However, three subcategories - physical, academic and social transitioning subsequently emerged.

The results of this study revealed that a sense of familiarity led to reduced support across all themes and subcategories of transition. For Mark, it was a physical and familial sense 
of familiarity (particularly as the student had attended since kindergarten) that reduced the support, and for Angus, a sense of familiarity was related to perceived expertise of staff with knowledge and experience in providing for students with AS. This expertise led to appropriate rhetoric by the executive from Shacklin School, but real evidence of support was lacking.

Also, across all of the findings, school staff from both schools appeared unaware that transition for people with AS is a continuing lifelong process. Successful transitions (for all students) depend on 'the recognition that becoming comfortable in a new setting is an ongoing process, not a single event' (Shoffner \& Williamson, 2000, p. 49).

In the literature positive adjustments for students with AS within a new environment reflect 'proactive planning' (Adreon \& Stella, 2001, p. 269). In this study another major finding was the lack of well-organised, systematic and ongoing collaboration between all participants, with the students not being involved at all. Both caregivers clearly perceived the need for ongoing collaborative support with the school and endeavoured to encourage this. Whereas Mark's mum was perceived by staff as a resource and 'support person', Angus's mum reported frustration and anxiety that resulted from minimal attention being paid to her advocacy role. She felt her knowledge of her son's needs was not valued or acknowledged. Although differing priorities were identified by all adult stakeholders, there was no mechanism in place for articulating these priorities together as a team. Both schools believed they were appropriately catering for the students' needs, but there were varying perceptions on the part of caregivers. There was no evidence provided by the stakeholders of collaborative planning or an awareness of the value of a consultative collaborative approach for students with AS. Similar to Hay and Winn (2005), consultation occurred predominantly 'when students with AS were causing ... some level of concern' (p. 150). This is of particular importance for the future of these students as they will be moving beyond the school to their postsecondary educational or vocational environments. As there is now a concerted effort to increase the self-determination role of students with AS and other disabilities, it will be important for these students to be given opportunities to develop self-determination skills.

In relation to the social subcategory, both schools had established structures for social integration and the control of playground issues (i.e., safe havens and model clubs), as recommended in the literature (Lawrence, 2010; Safran, 2002) as being useful when a student is transitioning between contexts and is 'overstimulated or has difficulty adjusting to a new activity or environment' (Bullard, 2004, p. 179). However, perhaps because they were not specifically tailored to the students' individual needs and, more important, the students were not consulted, neither accessed them in any significant way. The literature regarding students with a disability, in particular those with an intellectual disability, claims the involvement of 'young people and their parents/carers ... [as] major players in the transition process' (Laragy, 2004, p. 520) is mandatory. Involvement as a major player allows not only for all stakeholders to indicate their perceived knowledge of needs but also emphasises the need for differentiation linked to self-determination on the part of the student. Heatherington et al. (2010) claims the two key elements of transition and transition programs are direct involvement of the student and maximisation of self-determination. Although the direct voice of the student is not evident within this study from their interview data, the provision other stakeholders made for student voice and input about transition decisions is also clearly missing. Stakeholders provided no perception that the students' voices were important and there was no evidence of provision to empower them to indicate their needs. Saggers, Hwang, and Mercer (2011) '[recognise] the importance of listening to the voices of students with ASD' (p. 175). While the intention of this research 
is emancipatory, in part by attempting to provide 'some meaningful practical outcome' (Barnes, 2003, p. 12) regarding transition, an important question that should be considered is how can a shift occur between advocates knowing and claiming what is best for a student to actively including the student in decision-making and allowing them to voice what they see as appropriate for themselves? Through engaging with the students, stakeholders may discover how to enable transition and make it smoother for all parties as long as they ensure that the student voice is supported (Thoma, 1999). This interpretative approach would allow research to look beyond a status perspective. Therefore, rather than an adult-driven or advocacy perspective regarding transition procedures, the transitional needs and identified procedures should be examined through a multilensed perspective. The question is: What is the most effective method or medium to gain a valid perception of all stakeholders, and in particular students with AS?

The perception of physical transition support as being important is reflected in the identification and implementation of a range of strategies similar to those identified in the literature (Konza, 2005; Lawrence, 2010; Maras \& Aveling, 2006). Intellectual/academic transitioning, however, was not clearly indicated as important except by Angus's caregiver. It was presumed that both students were academically able and the support needed was minimal. School staff provided no recognition of the need to organise homework structures so that the transition of academic work from school to home allowed the student to understand the demands of the task very clearly and where the home could be supportive. This exacerbated the levels of stress and anxiety experienced in particular by Angus, his mum and other family members in the home setting. This 'home-school connection [as a] critical component of working with [students] with Asperger Syndrome' (Phemister, 2005, p. 63) was not recognised as an issue within the education context. Social transitioning was not really addressed and, where indicated, was on a reactive basis, particularly for Mark.

\section{Conclusion}

For the two schools that were the focus of this research, stakeholders in Shacklin School had more knowledge and awareness of AS, but both schools experienced difficulties with implementing successful ongoing strategies. These difficulties were distinctly linked to the lack of collaboration among all stakeholders, including the students. In fact, there was no student voice. This led to ineffective and inefficient provisions, particularly in the area of social transitions or provisions. Close, collaborative consultation and proactive planning with all stakeholders needs to be the real focus of ongoing transition — physically, academically, socially and from a home-school perspective.

\section{Limitations of the Research}

The limited number of participants and settings leads to a lack of generalisability to the population of students with AS. This is a characteristic of the qualitative paradigm, and the findings may not directly represent all the experiences of students, parents or teachers who are transitioning students with AS into and through high school. In addition, both the lack of engagement and lack of rich responses from Mark needs to be acknowledged. Perhaps, given the characteristics of students with AS, interviewing may be a research technique that requires greater refinement and indicates the need for the interviewer to develop greater familiarity with students with AS than with other participants. Or, more important, interviewing may not be the most appropriate medium for exploring the perceptions of this cohort of students for whom language-processing skills may hinder 
in-depth responses. However, Saggers et al. (2011) successfully used interview techniques in their qualitative study with students with ASD. Other limitations include, but are not limited to, the qualitative research paradigm. However, although this paradigm does not lead to generalisation of results, it does allow for validity and reliability through triangulation of the data that is guaranteed by multiple perspectives concentrating on one case. Being a convenience sample, it fitted the criteria or the focus of the study - students with AS being included in academically focused schools.

\section{Suggestions for Further Areas of Research}

Further research specifically needs to identify the student perspective. This study has identified that transition to high school is teacher- and/or caregiver-driven, not specifically student-driven. However, identification procedures would have to be specifically targeted at students who are willing or capable of participating in long semistructured interviews. Alternative methods of conducting interviews need to be acknowledged. These include cutting down the number of words in questions, using more direct language and using techniques to clarify the abstract. Also the use of students' preferences or interests to establish rapport and link to the areas that need to be discussed may be a useful strategy. The provision of visual and verbal links to social situations may be useful. However, all of these strategies also need to be validated by further research.

Future research should broaden the representation of subjects and schools and involve a longitudinal perspective where participants are followed from Year 6, throughout the transition process, and into Years 7, 8 and beyond. It would also be useful to investigate different forms of professional learning that can help teachers to identify effective interventions to assist students to transition within years and within contexts.

Furthermore, research is needed as to how to make transition planning more studentdirected (Agran, Blanchard, \& Wehmeyer, 2000) so that students with AS can become more active in the determination of their future. Finally, there needs to be recognition that transition planning is an ongoing process, and therefore further research is required in determining how this can be accomplished in high school settings that do not have a formal transition planning or individual education plans (IEP) process for their students with AS.

\section{Endnotes}

1 It is important to note that at the time of this writing, the American Psychiatric Association was revising the Diagnostic and Statistical Manual of Mental Disorders (DSM) for the upcoming fifth edition. The $D S M-V$ proposes to subsume Asperger syndrome under autistic disorder/autism spectrum disorder (American Psychiatric Association, 2012). Although this change may affect terms for future diagnosis, the term Asperger syndrome is used in this article, with the understanding that the term may soon be obsolete.

2 Pseudonyms have been used for schools and students.

\section{References}

Adreon, D., \& Durocher, J.S. (2007). Evaluating the college transition needs of individuals with high-functioning autism spectrum disorders. Intervention in School and Clinic, 42, 271-279. doi:10.1177/10534512070420050201 
Adreon, D., \& Stella, J. (2001). Transition to middle and high school: Increasing the success of students with Asperger syndrome. Intervention in School and Clinic, 36, 266-271. doi:10.1177/105345120103600502

Agran, M., Blanchard, C., \& Wehmeyer, M.L. (2000). Promoting transition goals and self-determination through student self-directed learning: The self-determination learning model of instruction. Education and Training in Mental Retardation and Developmental Disabilities, 35, 351-364.

Ainley, J. (1995). Students' views of their schools. Unicorn, 21, 5-16.

Akos, P. (2002). Student perceptions of the transition from elementary to middle school. Professional School Counseling, 5, 339-345.

American Psychiatric Association. (2012). DSM-V development. Retrieved October 19, 2012, from http://www.dsm5.org/Pages/Default.aspx

Attwood, T. (2007). A complete guide to Asperger's syndrome. London, UK: Kingsley.

Barnes, C. (2003). What a difference a decade makes: Reflections on doing 'emancipatory' disability research. Disability \& Society, 18, 3-17. doi:10.1080/713662197

Barnhill, G.P. (2004). Asperger syndrome: A guide for secondary school principals. Principal Leadership, 5(3), 11-15.

Braun, V., \& Clarke, V. (2006). Using thematic analysis in psychology. Qualitative Research in Psychology, 3, 77-101. doi:10.1191/1478088706qp063oa

Bullard, H.R. (2004). Ensure the successful of inclusion of a child with Asperger syndrome in the general education classroom. Intervention in School and Clinic, 39, 176-180. doi:10.1177/10534512040390030801

Corbin, J., \& Strauss, A. (2008). Basics of qualitative research (3rd ed.). Thousand Oaks, CA: Sage.

Creswell, J.W. (2007). Qualitative inquiry and research design: Choosing among five approaches (2nd ed.). Thousand Oaks, CA: Sage.

Dalton, A.C. (2009). Aiding in the transition from primary to secondary school. The Plymouth Student Educator, 1, 1-11.

Ennis, D., \& Manns, C. (2004). Breaking down the barriers to learning: Practical strategies for achieving successful transition for students with autism and Asperger syndrome. London, UK: DfES.

Frith, U. (2004). Confusions and controversies about Asperger syndrome. Journal of Cognitive and Behavioural Psychotherapies, 4, 103-130.

Ganeson, K., \& Ehrich, L.C. (2009). Transition into high school: A phenomenological study. Educational Philosophy and Theory, 41, 60-78. doi:10.1111/j.1469-5812.2008.00476.x

Geenen, S., Powers, L.E., \& Lopez-Vasquez, A. (2001). Multicultural aspects of parent involvement in transition planning. Exceptional Children, 67, 265-282.

Graetz, J.E., \& Spampinato, K. (2008). Asperger's syndrome and the voyage through high school: Not the final frontier. Journal of College Admission, Winter 2008(198), 19-24.

Hay, I., \& Winn, S. (2003). The sources of stress for special educators working in inclusive settings. In B. J. Bartlett, F. Bryer, \& D. Roebuck (Eds.), Reimagining practice: Researching change (Vol. 2, pp. 47-58). Brisbane, Australia: School of Cognition, Language and Special Education, Griffith University.

Hay, I., \& Winn, S. (2005). Students with Asperger's syndrome in an inclusive secondary school environment: Teachers', parents', and students' perspectives. Australasian Journal of Special Education, 29, 140-154. doi:10.1080/1030011050290206

Heatherington, S.A., Durant-Jones, L., Johnson, K., Nolan, K., Smith, E., Taylor-Brown, S., \& Tuttle, J. (2010). The lived experiences of adolescents with disabilities and their parents in transition planning. Focus on Autism and Other Developmental Disabilities, 25, 163-172. doi:10.1177/1088357610373760

Ivey, J.K. (2004). What do parents expect? A study of the likelihood and importance of issues for children with autism spectrum disorders. Focus on Autism and Other Developmental Disabilities, 19, 27-33. doi:10.1177/10883576040190010401

Jindal-Snape, D., Douglas, W., Topping, K.J., Kerr, C., \& Smith, E.F. (2006). Autistic spectrum disorders and primary-secondary transition. International Journal of Special Education, 21(2), 18-31. Retrieved August 3, 2011, from http://www.internationalsped.com/documents/03Jindalsnape.doc

Konza, D. (2005). Secondary school success for students with Asperger's syndrome. Australasian Journal of Special Education, 29, 128-139. doi:10.1080/1030011050290205 
Laragy, C. (2004). Self-determination within Australian school transition programmes for students with a disability. Disability \& Society, 19, 519-530. doi:10.1080/0968759042000235343

Lawrence, C. (2010). Successful school change and transition for the child with Asperger syndrome: A guide for parents. London, UK: Kingsley.

Maras, P., \& Aveling, E.-L. (2006). Students with special educational needs: Transitions from primary to secondary school. British Journal of Special Education, 33, 196-203. doi:10.1111/j.1467-8578.2006.00439.x

McMaugh, A., \& Debus, R. (2000, November). "Just make friends, that's the most important thing!" School transition and making friends. The concerns and worries of children with illness and disability. Paper presented at the AARE-NZARE 1999 Conference, Melbourne, Australia. Retrieved June 2, 2011, from http://www.aare.edu.au/99pap/mcm99171.htm

Newsome, W.S. (2000). Parental perceptions during periods of transition: Implications for social workers serving families coping with autism. Journal of Family Social Work, 5(2), 17-31. doi:10.1300/J039v05n02_03

NSW Department of Education and Training (NSW DET). (2006). Our middle years learners — Engaged, resilient, successful: An education strategy for Years 5-9 in NSW 2006-2009. Retrieved August 3, 2010, from https://www.det.nsw.edu.au/media/downloads/newsroom/yr2006/oct/middleyrs.pdf

NSW Department of Education and Training (NSW DET). (2009). 2009 Selective High School and Opportunity Class Placement Unit: Year 7 entry to selective high schools application package. Sydney, Australia: Educational Measurement and School Accountability Directorate, NSW Department of Education and Training. Retrieved from http://www.schools.nsw.edu.au/media/downloads/ schoolslearning/k_6assessments/ss_apppackage.pdf

Patton, J.R., Cronin, M.E. \& Jairrels, V. (1997). Curricular implications of transition: Life skills instruction as an integral part of transition education. Remedial and Special Education, 18, 294-306. doi:10.1177/074193259701800505

Phemister, A. (2005). Reaching kids with Asperger's syndrome. The Education Digest, 71(2), 5863.

Roeser, R.W., Midgley, C., \& Urdan, T.C. (1996). Perceptions of the school psychological environment and early adolescents' psychological and behavioral functioning in school: The mediating role of goals and belonging. Journal of Educational Psychology, 88, 408-422. doi:10.1037/0022-0663.88.3.408

Rossetti, Z.S., \& Goessling, D.P. (2010). Paraeducators roles in facilitating friendships between secondary students with and without autism spectrum disorders or developmental disabilities. Teaching Exceptional Children, 42(6), 64-70.

Rubin, H.J., \& Rubin, I.S. (2005). Qualitative interviewing: The art of hearing data (2nd ed.). Thousand Oaks, CA: Sage.

Safran, J.S. (2002). Supporting students with Asperger's syndrome in general education. Teaching Exceptional Children, 34(5), 60-66.

Saggers, B., Hwang, Y.-S., \& Mercer, K.L. (2011). Your voice counts: Listening to the voice of high school students with autism spectrum disorder. Australasian Journal of Special Education, 35, 173-190. doi:10.1375/ajse.35.2.173

Shoffner, M.F., \& Williamson, R.D. (2000). Facilitating student transitions into middle school. Middle School Journal, 31(4), 47-52.

Stake, R.E. (2006). Multiple case study analysis. New York, NY: Guilford.

Thoma, C.A. (1999). Supporting student voice in transition planning. Teaching Exceptional Children, $31(5), 4-9$.

Yin, R.K. (2009). Case study research: Design and methods (4th ed.). Thousand Oaks, CA: Sage.

Webb, J.T., Amend, E.R., Webb, N.E., Goerss, J., Beljan, P., \& Olenchak, F.R. (2005). Misdiagnosis and dual diagnoses of gifted children and adults: ADHD, bipolar, OCD, Asperger's, depression, and other disorders. Scottsdale, AZ: Great Potential.

Wehman, P., \& Thoma, C. (2006). Teaching for transition. In P. Wehman (Ed.), Life beyond the classroom: Transition strategies for young people with disabilities (4th ed., pp. 201-236). Baltimore, MD: Brookes.

Winn, S., \& Hay, I. (2009). Transition from school for youths with a disability: Issues and challenges. Disability \& Society, 24, 103-115. doi:10.1080/09687590802535725 


\begin{tabular}{|c|c|c|c|c|}
\hline \multicolumn{5}{|c|}{ Before Year 7} \\
\hline & Executive & Teacher & Caregiver & Student \\
\hline PHYSICAL & $\begin{array}{l}\text { - Given timetable } \\
\text { - Visit to classrooms - physical } \\
\text { and sensory orientation with } \\
\text { peer support to campus } \\
\text { - All books provided } \\
\text { - Suggested labelling } \\
\text { - Locker padlock not combination } \\
\text { - Viewed locker - placement first } \\
\text { in section }\end{array}$ & $\begin{array}{l}\text { - Frequent familiarising visits to Year } 6 \\
\text { - Photos of staff as requested by mum (to assist } \\
\text { with camp) }\end{array}$ & $\begin{array}{l}\text { - Provided visuals, photos of staff, } \\
\text { maps and lockers, timetables and } \\
\text { suggested practise packing bag } \\
\text { - Coordination meeting with head of } \\
\text { middle school - (P/A/S) }\end{array}$ & $\begin{array}{l}\text { - 'Mum and speech } \\
\text { pathologist helped } \\
\text { pack bag, the } \\
\text { timetable and stuff' }\end{array}$ \\
\hline ACADEMIC & $\begin{array}{l}\text { - Year } 6 \text {, Year } 7 \text { and learning } \\
\text { support teacher meeting } \\
\text { - O \& A forum (A/S) }\end{array}$ & $\begin{array}{l}\text { - Meeting with speech pathologist } \\
\text { - } \mathrm{Q} \text { \& A forum (A/S) }\end{array}$ & $\begin{array}{l}\text { - Q \& A forum: Speech pathologist } \\
\text { and parent (P/A/S) } \\
\text { - 'Weaned him off TAS' (teacher } \\
\text { aide) - her initiative }\end{array}$ & \\
\hline SOCIAL & - Buddy system & & - Buddy system & \\
\hline \multicolumn{5}{|c|}{ Beginning Year 7} \\
\hline PHYSICAL & & & - Caregiver attended camp & \\
\hline ACADEMIC & $\begin{array}{l}\text { - Update learning support } \\
\text { register (LSR) } \\
\text { - Hard copy of LSR to faculty } \\
\text { heads } \\
\text { - Email to individual teachers } \\
\text { only information in LSR } \\
\text { relating to their specific } \\
\text { students (P/A/S) }\end{array}$ & $\begin{array}{l}\text { - Meeting with head teacher - all teachers with } \\
\text { students with individual needs (A/S) } \\
\text { - Access to LSR } \\
\text { - Information provided from junior school } \\
\text { (P/A/S) }\end{array}$ & & \\
\hline SOCIAL & & Camp - placed with students he already knew & & $\begin{array}{l}\text { - Most difficult time was } \\
\text { camp - 'not knowing } \\
\text { what would happen' }\end{array}$ \\
\hline \multicolumn{5}{|c|}{ Throughout Year } \\
\hline PHYSICAL & $\begin{array}{l}\text { - Transitioning to playground - } \\
\text { created 'safe haven' in the } \\
\text { library } \\
\text { - Model club }\end{array}$ & $\begin{array}{l}\text { - 'Safe haven' in library } \\
\text { - 'Tried to get him in a club' } \\
\text { - Special provision room for exams }\end{array}$ & $\begin{array}{l}\text { - 'On call' } \\
\text { - At home - assists with timetables, } \\
\text { etc., and prepares him for } \\
\text { changes when informed by staff }\end{array}$ & $\begin{array}{l}\text { No response to } \\
\text { questions about Year } \\
8 \text { except - 'It will be } \\
\text { good!' }\end{array}$ \\
\hline ACADEMIC & - Academic - timetable exam & $\begin{array}{l}\text { - Ongoing meetings with staff } \\
\text { - Regular email contact with staff regarding } \\
\text { needs } \\
\text { - Mentor to staff - structure, routines and } \\
\text { adjustments to academic needs }\end{array}$ & & \\
\hline
\end{tabular}

Note. $\mathrm{P}=$ physical transition procedures; $\mathrm{A}=$ academic transition procedures; $\mathrm{S}=$ social transition procedures. 


\begin{tabular}{|c|c|c|c|c|}
\hline $\begin{array}{l}\text { Appendix } \\
\text { Shacklin S }\end{array}$ & ol: Perceived Transition Procedures b & II Stakeholders Before, Beg & g and Throughout Year 7 & \\
\hline \multicolumn{5}{|c|}{ Before Year 7} \\
\hline & Executive & Teacher & Caregiver & Student \\
\hline PHYSICAL & $\begin{array}{l}\text { - Support teacher (autism) created } \\
\text { resources to support transition - } \\
\text { including visual booklet, copies of } \\
\text { timetables, map of school } \\
\text { - Executive met with student in primary } \\
\text { school setting }\end{array}$ & $\begin{array}{l}\text { - Mother organised visits to } \\
\text { school }\end{array}$ & $\begin{array}{l}\text { - School visits arranged by } \\
\text { mother } \\
\text { - Support teacher created visual } \\
\text { transition booklet and } \\
\text { worksheets related to high } \\
\text { school including expectations } \\
\text { - maps, checklists, planners, } \\
\text { timetables }\end{array}$ & $\begin{array}{l}\text { - Individual visit to school } \\
\text { - Maps of school provided. } \\
\text { Year advisors 'showed me } \\
\text { around' }\end{array}$ \\
\hline ACADEMIC & $\begin{array}{l}\text { - Planning with support teacher autism } \\
\text { from primary school (P/A/S) } \\
\text { - Information presented to high school } \\
\text { learning support team }\end{array}$ & $\begin{array}{l}\text { - List from primary school } \\
\text { - Patron teacher allocated - } \\
\text { linked to student's strength }\end{array}$ & $\begin{array}{l}\text { - Year } 6 \text { teacher's repeated } \\
\text { comments linked to } \\
\text { anticipated increase in } \\
\text { homework (A) and } \\
\text { behavioural expectations (A/S) } \\
\text { - Support teacher (autism) - link } \\
\text { between primary school and } \\
\text { high school. }\end{array}$ & $\begin{array}{l}\text { - Year advisors available for } \\
\text { subject queries }\end{array}$ \\
\hline \multicolumn{5}{|l|}{ SOCIAL } \\
\hline \multicolumn{5}{|c|}{ Beginning Year 7} \\
\hline PHYSICAL & & & $\begin{array}{l}\text { - Caregiver colour coded } \\
\text { timetable subjects and related } \\
\text { books } \\
\text { - Caregiver placed sleeve/pocket } \\
\text { in front of each book for } \\
\text { notes/assignments, etc. (P/A) }\end{array}$ & $\begin{array}{l}\text { - Changing teachers for subjects } \\
- \text { 'confusing at first' }\end{array}$ \\
\hline ACADEMIC & & $\begin{array}{l}\text { - Patron teacher informs staff } \\
\text { who will teach student from } \\
\text { year to year (A/S) } \\
\text { - Information sheets for staff } \\
\text { (A/S) }\end{array}$ & $\begin{array}{l}\text { - Letter given to learning support } \\
\text { coordinator from caregiver } \\
\text { (A/S) }\end{array}$ & $\begin{array}{l}\text { - Written timetable provided } \\
\text { (A/P) }\end{array}$ \\
\hline SOCIAL & $\begin{array}{l}\text { - Year } 7 \text { camp: } 1 \text { st week of school (S) } \\
\text { - Individual programs at camp to support } \\
\text { students with specific identified needs } \\
\text { (S/A) }\end{array}$ & & $\begin{array}{l}\text { - Year } 7 \text { camp - small groups of } \\
10\end{array}$ & $\begin{array}{l}\text { - Key difficulty - not all students } \\
\text { from same school. 'Making } \\
\text { friends. I didn't make new } \\
\text { friends very easily' }\end{array}$ \\
\hline
\end{tabular}




\section{Appendix B}

Continued

\begin{tabular}{|c|c|c|c|c|}
\hline & Executive & Teacher & Caregiver & Student \\
\hline \multicolumn{5}{|c|}{ Throughout Year } \\
\hline PHYSICAL & & $\begin{array}{l}\text { - 'Safe haven' allocated near } \\
\text { patron teacher location }\end{array}$ & & \\
\hline ACADEMIC & $\begin{array}{l}\text { - Year advisors and executive inform new } \\
\text { teachers of these students and } \\
\text { individual needs each semester } \\
\text { - Learning support team - parent } \\
\text { meetings twice a year }\end{array}$ & $\begin{array}{l}\text { - Professional development } \\
\text { - 'A lot is done behind the scenes } \\
\text { with } M \text { by [executive }]^{\prime}(\mathrm{P} / \mathrm{A} / \mathrm{S}) \\
\text { - Ongoing contact with caregiver } \\
\text { - formal and informal }\end{array}$ & $\begin{array}{l}\text { - Term } 2 \text { - aide time 'worked } \\
\text { out' } \\
\text { - Arranged meeting with } \\
\text { learning support coordinator } \\
\text { each semester } \\
\text { - Arranged meetings with } \\
\text { individual teachers to discuss } \\
\text { current issues } \\
\text { - Caregiver assists him with } \\
\text { academic organisational } \\
\text { procedures - for school and } \\
\text { home }\end{array}$ & \\
\hline SOCIAL & $\begin{array}{l}\text { - Regular meetings with students with AS } \\
\text { working on social skills/needs } \\
\text { - Examples of current programs and } \\
\text { support - 'Circle of friends' } \\
\text { - Another = one-on-one emotional } \\
\text { support (S) }\end{array}$ & & & \\
\hline
\end{tabular}

Note. $\mathrm{P}=$ physical transition procedures; $\mathrm{A}=$ academic transition procedures; $\mathrm{S}=$ social transition procedures. 